\title{
Detection Method to Prevent Reference Omissions Using Logs of Text Inserted by Copy-and-Paste Operations
}

\author{
Chikako ISHIZAWA*, Masahiro TOSHIMA**, Yoichi KAGEYAMA* and Makoto NISHIDA*** \\ ${ }^{*}$ Department of Mathematical Science and Electrical-Electronic-Computer Engineering, \\ Graduate School of Engineering Science, \\ Akita University, 1-1, Tegata Gakuen-machi, Akita-shi, Akita 010-8502, Japan \\ ${ }^{* *}$ Department of Computer Science and Engineering, Faculty of Engineering and Resource Science, \\ Akita University, 1-1, Tegata Gakuen-machi, Akita-shi, Akita 010-8502, Japan \\ *** The Open University of Japan, 1-1, Tegata Gakuen-machi, Akita-shi, Akita 010-8502, Japan \\ E-mail:ishizawa@ie.akita-u.ac.jp
}

\begin{abstract}
The objective of this study is to prevent human mistakes, specifically, omitting reference lists and reference numbers that should be appended to a copied text. When sentences are created using a personal computer (PC), it is possible to copy and use text from the Internet. However, a user will occasionally forget to include the copy-source information, e.g., the URL or webpage title, in the reference list or to add the reference number to the inserted text. Therefore, we propose a method that obtains the relevant logs from the PC, detects the text inserted by a copy-and-paste operation, and shows the copy-source information to the user. The proposed method consists of three processes. The first process monitors the clipboard state and creates logs with the copy-source information, e.g., the webpage title or the URL. Thereafter, the text-detection process calculates the cosine similarity between the copy-source sentences and the user's text. Text with no reference information is detected based on the cosine-similarity value. Finally, the reference information for the detected text is displayed on the monitor. Various changes were made to the inserted text by using Microsoft Windows 7. Our experimental results showed that the proposed method can detect inserted text without reference information and display the necessary information in the reference list.
\end{abstract}

Keywords : Text detection, cosine similarity, log analysis

\section{INTRODUCTION}

The penetration rate of the Internet is increasing along with the development of information and communication technology [1]. Because extensive information can be easily obtained, the Internet is an effective research tool and is sometimes used when creating documents, e.g., papers and reports. For instance, when creating sentences (text) by using a personal computer (PC), it is possible to copy and use text that appears on the Internet.

However, the illegal use of copyrighted work is increasing with the spread of the Internet $[2,3]$. Because images and text on the Internet are protected by copyright, it is necessary to obtain the author's consent, or at least provide a reference, when using them.

However, people occasionally forget to include the copy-source information, e.g., URL and webpage title, in the reference list or to add a reference number to the inserted text. For instance, according to a survey conducted by the Japan Science and Technology Agency (JST), approximately $60 \%$ of the 114 research frauds published in Japanese newspapers, etc., from 1977 to 2012, did not obtain the author's consent or provide a reference [2]. The causes of illegal use include "mistakes, carelessness, immaturity, inappropriate treatment" (13.8\%), "insufficient recognition, misunderstanding" (13.3\%), and "busy" (1.6\%) [3]. Thus, approximately $30 \%$ (28.7\%) of the uses were unintentional. Therefore, we believe that it is necessary to call attention to including references when creating papers and reports.

One product that can manage reference information is Microsoft Word $^{\circledR}$ (Microsoft Corp.) [4]. Word has a function for managing the reference information entered by the user. Thus, it is possible to reuse the reference information in other Word files. However, users are burdened by entering the information. Therefore, obtaining the reference information automatically will help them.

Copypelna (ANK Co., Ltd.) has another useful function [5]. The document file created by a user is compared with text on the Internet. It presents the user with a webpage or file that has identical or similar sentences. This product is suitable for checking documents by third parties, rather than preventing mistakes by a user. It would be helpful to the user if mistakes were pointed out during document creation rather than finding a mistake after the document file is completed.

Based on the above situation, to prevent unintentional omission of references, it is necessary to present the reference and reference information of the sentence to the user when he/she is storing the document file or finishing the work. Therefore, we propose a method that obtains relevant logs from the PC, detects the inserted text, and finds the text without reference information, and displays the necessary information in the reference list to the user. Microsoft Windows ${ }^{\circledR}$ was the operating system of the PC used in this study. 


\section{DETECTION TARGET}

There are two usage types for text inserted into a file through a copy-and-paste operation.

- Usage 1: The inserted text is not changed.

- Usage 2: The inserted text is changed, summarized, etc. We define usage 1 as a "citation" and usage 2 as a "reference," and search for texts without information among those created by "citations" or "references."

\section{PROPOSED METHOD}

\subsection{Outline of proposed method}

The advantage of the proposed method is that it can log copysource information when a copy operation is performed. We believe that the proposed method can provide users with reliable information for making reference lists by using logs. An outline of the proposed method is shown in Figure 1. The proposed method consists of three integrated processes: the process to obtain logs, the process to detect text without reference information, and the process to display detection results. To facilitate the experiment, the judgment of the file-save operation and the work termination is performed manually.

\subsection{Process to obtain logs}

When a copy operation is performed on a PC, the copied data are stored to the clipboard of the PC, as shown in Figure 2. The clipboard is an area in the main memory where data are temporarily stored during a copy operation. Usually, the amount of data stored in the clipboard correspond to a single copy operation. Thus, the data in the clipboard are rewritten if a subsequent copy operation is executed. As a result, the time when the clipboard's contents begin to be rewritten corresponds to the start of the copy-and-paste operation.

Using the Windows API library [6], it is possible to receive a notification when the contents of the clipboard are changed. It is also possible to obtain the clipboard's contents. Therefore, the obtain-log process monitors the state of the clipboard and records the logs when the content of the clipboard changes. That is, when the obtain-log process receives the content change notice for the clipboard, it records date and time, a webpage title, a URL, and the copied text data. Figure 3 shows an example of the obtained logs. Characters enclosed in double quotes are data of each item. In the case of copying from the web browser, since the title of the webpage is recorded in the item "window title", in this study, the item "window title" is called "webpage title". The three types of item, excluding the copied text data, are items recommended by the Japan Science and Technology Agency [7].

\subsection{Process to detect text}

Figure 4 shows the flow for the text-detection process. It consists of three integrated processes: (1) a URL-detection processing for determining whether the reference information is appropriately described, (2) a detecting processing whether a sentence created by citation requires a description of the reference information, and (3) a detecting processing whether a sentence created by reference requires a description of the reference information.

First, a log is read out, and the process to detect the URL is executed. As a result, if the URL is not found, the processes to detect text created by a citation or a reference are executed. The log reading is then repeated until the last log is reached.

In the URL-detection processing (processing (1)), all the text in the file is searched for the URL recorded in the log. If the exact URL is found, it is judged that "the reference information

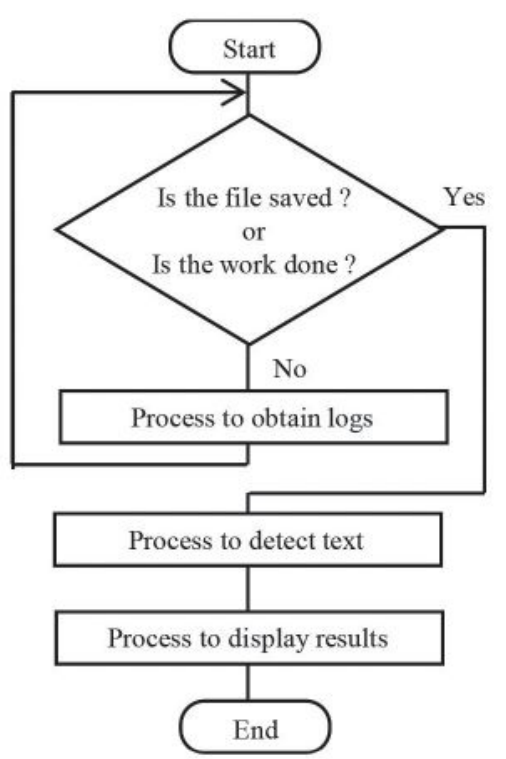

Figure 1 Outline of proposed method for detecting inserted text without reference information

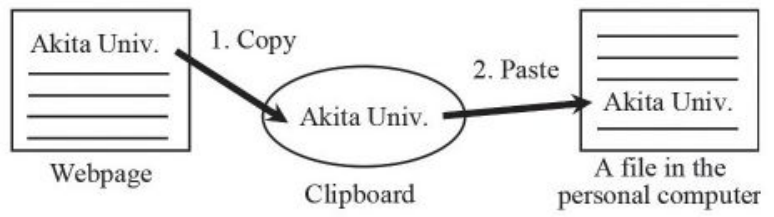

Figure 2 Steps for inserting text using a copy-and-paste operation

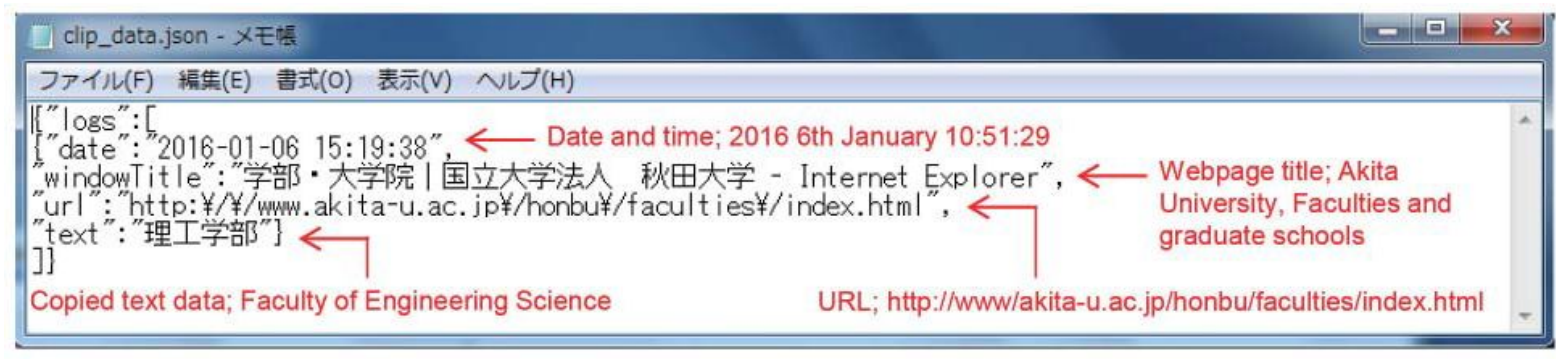

Figure 3 Example of obtained logs 


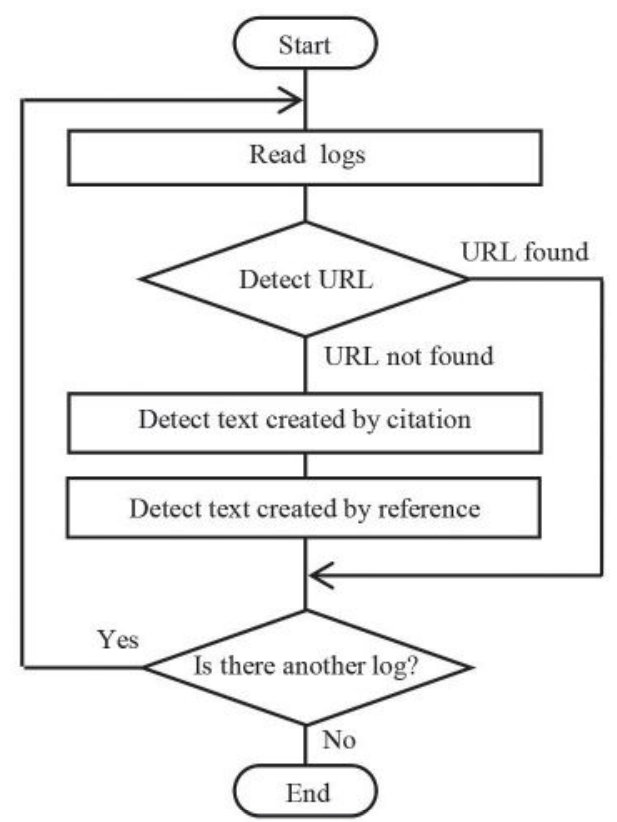

Figure 4 Flow for text-detection process

is appropriately described," and it returns to the log-reading processing. However, if the exact URL is not found, it is judged that "the reference information is not appropriately described," and the detection processing of text created by citation is executed.

In the detection processing of text created by citation (process (2)), the copied text data recorded in the log are compared against all the text in the file. If the exact text data are found, it is judged that "the detected text was created by citation," and the text is highlighted in yellow. However, if the exact text data are not found, it is judged that "no text was created by citation." When all the text in the file has been searched, the detection processing of text created by reference is executed.

In the detection processing of text created by reference (process (3)), a morphological analysis [8-10] is executed on the copied text data recorded in the log and the text in the file. Thereafter, the cosine similarity $[9,10]$ between the text data in the log (copysource sentences) and the text in the file is calculated. Two types of cosine similarity are calculated: "Only using nouns" and "using nouns and verbs;" the larger value is adopted.

Finally, if the cosine similarity value is 0.5 or more, it is judged that "the two sentences have similar meanings," indicating that the text was created by reference. The detected text is highlighted in blue. However, when the cosine similarity value is less than 0.5 , it is judged that "the text was not created by reference." When all the text in the file has been searched, execution returns to the logreading processing. The cosine similarity indicates the similarity between sets, and is calculated by the following formula $[9,10]$.

$$
\text { Cosine }(X, Y)=\frac{|X \cup Y|}{\sqrt{|X||Y|}}
$$

where $\mathrm{X}$ and $\mathrm{Y}$ mean sets. The cosine similarity takes a value between 0 and 1 ; as the value approaches 1 , it indicates that the set is similar. Thus, a judgment based on the cosine similarity is possible by executing a morphological analysis on the text and creating sets of nouns. The cosine-similarity threshold value of 0.5 was determined empirically. Specifically, we examined the

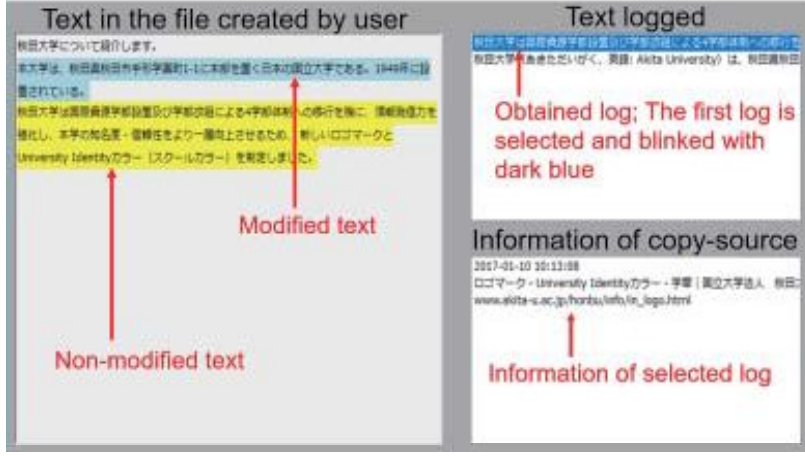

Figure 5 Indication window with the detection results

cosine similarity when 16 subjects arbitrarily modified five single original sentences included from 10 to 21 words. As a result, there were cases where sentences to be detected were not detected when the threshold value was 0.6 , and there were cases where irrelevant sentences were detected when the threshold value was 0.4 . To prevent undetected related sentences, the threshold value was determined to be 0.5 .

3.4 Process to display detected text and reference information

Figure 5 shows an indication window with the detection results. The left area shows the sentences read from the document file created by the user. In the sentences that the user created, the sentences that were judged to have been created by citation are highlighted in yellow, and the sentences judged to have been created by reference are highlighted in blue.

The upper right area shows the obtained logs. The sentences copied from the webpage recorded in the log. One log is displayed by one line. The selected log is blinked with dark blue.

The lower right area shows the reference information corresponding to the sentence selected in the upper-right area. When the selected sentence changes, the display of the reference information also changes.

\section{EXPERIMENTAL CONDITIONS}

To verify the usefulness of using the proposed method, we conducted three types of experiments. Specifically, to verify the authenticity of the log-obtain processing, we experimented with detecting text created by citation. Thereafter, to evaluate the usefulness of using the cosine similarity, we experimented with detecting text created by reference. Finally, to verify the usefulness of the detection processing, we experimented with detecting text of both citation and reference. The experimental conditions are as follows:

- OS: Microsoft Windows ${ }^{\circledR} 7$ Pro. 64 bit

- CPU: Intel ${ }^{\circledR}$ Xeon $^{\circledR}$ CPU E5620 2.40 GHz

- Morphological analysis engine: NMeCab $0.07[11,12]$

- Dictionary for morphological analysis: mecab-ipadicNEologd [13]

- List of stop words: SlothLib [14]

A stop word is a word to be excluded when processing a natural language, e.g., "a," "the," and "for."

\subsection{Detection of text created by citation}

In this study, we defined a text that is not changed after pasting it as "citation." The fact that the detection of the text created by 
Table 1 Operation of copy and paste used

\begin{tabular}{|c|c|}
\hline Copy operation & Paste operation \\
\hline Pressing "ctrl" and "c" key & Pressing "ctrl" and "v" key \\
\hline $\begin{array}{l}\text { Click the right mouse button and } \\
\text { select "copy" from displayed } \\
\text { menu }\end{array}$ & $\begin{array}{l}\text { Click the right mouse button } \\
\text { and select "paste" from } \\
\text { displayed menu }\end{array}$ \\
\hline & $\begin{array}{l}\text { Select "paste" from menu of } \\
\text { Notepad }\end{array}$ \\
\hline
\end{tabular}

"citation" is accurate implies that the log-obtain processing is accurately executed. Therefore, when the following three types of operations were performed, the detection result and the contents of the log were confirmed.

- Operation 1: Copy one sentence from the webpage, and paste it in the file opened in Notepad.

- Operation 2: Copy a part of sentence from the webpage, and paste it in the file opened in Notepad.

- Operation 3: Copy one sentence or a part of the sentence from the webpage, however do not paste it.

As listed in Table 1, two types of copy operation and three types of paste operation were performed, respectively.

\subsection{Detection of text created by reference}

To verify the usefulness of using the cosine similarity, we experimented with detecting text created by reference. When a text is created by reference, the text inserted in the file is modified. We investigated the cosine similarity when six types of original Japanese sentences inserted in the file were modified. Table 2 shows the modification methods used in the experiment. Table 3 shows the relation between the original sentences and the modification methods. Figure 6 shows an example of original Japanese sentence. Other original sentences are shown in the appendix. The subjects are 16 persons (subjects A-P) in their twenties who routinely operate PCs.

\subsection{Detection of text created by citation and reference}

To verify the usefulness of the detection processing, we experimented with detecting text of both citation and reference. The subjects are four persons (subjects Q-T) in their twenties, who routinely operate PCs.

In the experiment, the subjects surveyed a given theme using the Internet, and provided an explanation in one file. When the file writing was completed, the proposed method was executed and the text inserted from the webpage was detected. The subjects were given the following conditions:

- Create one or more sentences using a citation and reference

- Make a line break when the meaning of the sentence changes In the detection processing of text created by reference, the cosine similarity between the text data in in the log and all text in the file is calculated. That is, the proposed method has not yet implemented the processing to narrow down the sentences to be compared. Therefore, in experiments, sentences appearing between the line breaks were used as comparison targets.

\section{RESULT AND DISCUSSION}

\subsection{Detection of text created by citation}

Table 4 shows the detection results of sentence created by citation. The detection result for each operation is correct. Figure 7 shows an example of the detection result when a part of the sentence is copied (Operation 2). Even if a part of the sentence is
Table 2 Modification methods in experiment

\begin{tabular}{ll}
\hline No. & \multicolumn{1}{c}{ Modification } \\
\hline 1 & Change a single original sentence to multiple sentences \\
\hline 2 & Change multiple original sentences to a single sentence \\
\hline 3 & $\begin{array}{l}\text { Change multiple original sentences to multiple different } \\
\text { sentences }\end{array}$ \\
\hline
\end{tabular}

Table 3 Modification methods applied to six types of original sentences

\begin{tabular}{lc}
\hline Sentence number & Modification method number \\
\hline 1 (single sentence) & 1 \\
\hline 2 (single sentence) & 1 \\
\hline $3(2$ sentences $)$ & 2 \\
\hline $4(3$ sentences $)$ & 2 \\
\hline $5(3$ sentences $)$ & 3 \\
\hline $6(4$ sentences $)$ & 3 \\
\hline
\end{tabular}

人工知能とは、人工的にコンピュータ上などで人閒と同様 の知能を実現させようという試みや技術のことで、AlphaGo や自動運転システムなどの特定の分野に特化した弱いAI(特 化型人工知能)と、人間のような汎化能力を備えた強いAI(汎 用人工知能) 02 種類に分かれます。

(Artificial intelligence is an attempt to artificially realize the same intelligence as a human being by a computer, or the like, and technology, and is divided into two types: weak AI, specialized in a specific field such as AlphaGo and automatic driving system (specialized artificial intelligence), and strong $\mathrm{AI}$, with generalization ability like a human (general purpose artificial intelligence).

Figure 6 Example of original sentence (No. 1)

Table 4 Detection results of sentence created by citation

\begin{tabular}{cll}
\hline Operation number & Detected sentence & Judgment \\
\hline 1 & One sentence copied & Success \\
\hline 2 & A part of sentence copied & Success \\
\hline 3 & None & Success \\
\hline
\end{tabular}

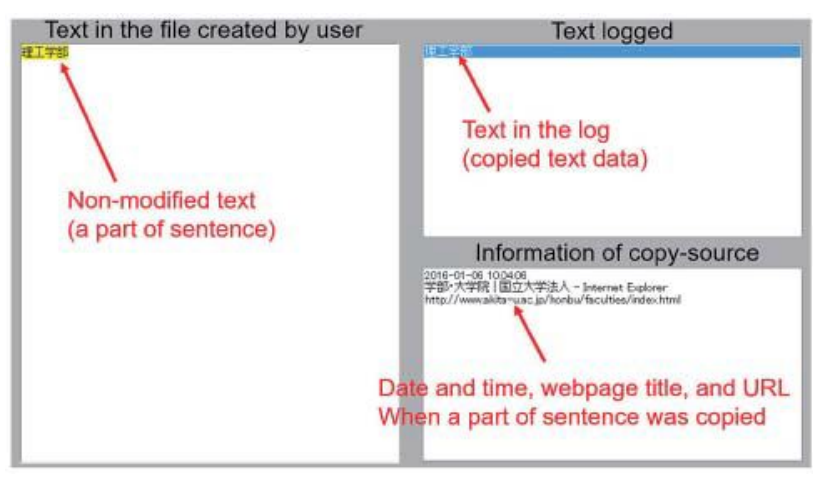

Figure 7 Example of detection results when text created by citation (Operation 2) 
the second and third logs in Figure 10(b) are highlighted in yellow. This result means that an erroneous detection occurred for the above reason. The proposed method assumed that the modification was done after copying one or more complete sentences, not part of the sentence. Therefore, a future task will be to investigate the various operation methods performed by users and to study countermeasures to properly judge citation/reference.

\section{CONCLUSION}

This paper proposed a method to detect text copied from the Internet and assign appropriate reference information. The proposed method was able to obtain relevant logs from the PC, detect the inserted text, find the texts without reference information, and display the necessary information in the reference list. The following results were obtained:

(a) Using $\log$ s that record information about the copy-source makes it possible to detect the sentences created by "citation" and provide the necessary information to the reference list.

(b) Searching for inserted text by focusing on sets of words in the sentences is useful, even if the number of sentences is changed. Cosine similarity can be an indicator of sentence relation before and after modification.

In future studies, narrowing down sentences to be compared with target, and detecting a sentence created by modifying copied sentences will be considered. We also consider to detect summarized sentences.

\section{Acknowledgment}

The authors would like to thank Dr. T. Takahashi from Akita University for his help in conducting these experiments.

\section{References}

[1] Ministry of Internal Affairs and Communications, "Result of communication trend survey $2015, " \mathrm{http}: / /$ www.soumu. go.jp/johotsusintokei/statistics/data/160722_1.pdf (Accessed 2017/01/06)
[2] Matsuzawa T., "Research misconduct in Japan: Macroanalysis based on open information (1)," Journal of Information Processing and Management, 56-3, 156-165 (2013).

[3] Matsuzawa T., "Research misconduct in Japan: Macroanalysis based on open information (2)," Journal of Information Processing and Management, 56-4, 222-235 (2013).

[4] Microsoft Corp., "Word," https://products.office.com/ja-jp/ word (Accessed 2017/01/06)

[5] ANK Co., Ltd, "Copypelna," http://www.ank.co.jp/works/ products/copypelna/(Accessed 2017/01/06)

[6] Solomon, D. and Russinovich, M., "Inside Microsoft Windows: The fourth edition," Nikkei BP Soft Press (2005).

[7] Japan Science and Technology Agency, "Description of Bibliographic References," http://jipsti.jst.go.jp/sist/handbook/ sist02_2007/main.htm (Accessed 2017/01/13)

[8] "mecab-ipadic-NEologd: Neologism dictionary for MeCab," https://github.com/neologd/mecab-ipadic-neologd (Accessed 2017/01/13)

[9] Okazaki N. and Tsuji J., "A Simple and Fast Algorithm for Approximate String Matching with Set Similarity," Journal of Natural Language Processing, 18-2, 89-117 (2011).

[10] Aizawa, A., "On Calculating Word Similarity Using Large Text Corpora," Journal of Information Processing Society of Japan, 49-3, 1426-1436 (2008).

[11] "NMeCab - .NET Morphological analyser," https://ja.osdn. net/projects/nmecab/(Accessed 2017/01/10)

[12] "MeCab: Yet Another Part-of-Speech and Morphological Analyzer," http://taku910.github.io/mecab/(Accessed 2017/01/10)

[13] "IPA dic legacy," https://ja.osdn.net/projects/ipadic/(Accessed 2017/01/22)

[14] "SlothLib," http://www.dl.kuis.kyoto-u.ac.jp/slothlib/ (Accessed 2017/01/13) 
Appendix: Original sentence used

\begin{tabular}{ll}
\hline $\begin{array}{c}\text { Sentence } \\
\text { number }\end{array}$ & Contents of sentences \\
\hline & 人工知能とは、人工的にコンピュータ上などで人間と同様の知能を実現させようという試みや技術のことで、
\end{tabular}

AlphaGoや自動運転システムなどの特定の分野に特化した弱いAI(特化型人工知能)と、人間のような沉化能力を備え た強いAI(汎用人工知能)の 2 種類に分かれます。

1 Artificial intelligence is an attempt to artificially realize the same intelligence as a human being by a computer, or the like, and technology, and is divided into two types: weak AI, specialized in a specific field such as AlphaGo and automatic driving system (specialized artificial intelligence), and strong AI, with generalization ability like a human (general purpose artificial intelligence).

ヒューマンコンピュータインタラクションとは、人とコンピューターの関連を調ベることで、人がコンピューター をより効率的に使えるような設計を研究する分野であり、グラフィックデザインのほか、コンピューターサイエン ス、情報科学、人間工学、認知エンジニアリング、心理学、社会学といった分野との相互関連も見られます。

2 Human-computer interaction investigates the relationship between a person and a computer, and it is a field that studies designs that enable people to use computers more efficiently. Additionally, there is a correlation to graphic design, computer science, information science, ergonomics, cognitive engineering, psychology, sociology.

学部教育において、理系基䃈科目の理解増進による論理的に考える力に加えて、英語と実践教育科目の強化により、 グローバル社会で即戦力として活躍する人材を育成することが本学部の理念です。これにより理学・数学から理工 学、工学の多面的な学問分野 で、身につけた深い基礎学力と新しい発想によって新時代の諸課題にたくましく取り 組む人材を育成することを目的とします。

3 In undergraduate education, in addition to the logical thinking power created by promoting an understanding of basic science courses, through strengthening English and practical education courses, the idea of this faculty is to nurture talent who will be active as an immediate fighting force in the global society. By doing this, we aim to nurture talented people who positively confront the problems of the new age by using deep basic academic ability and new ideas acquired in the multidisciplinary academic fields of science, mathematics, and engineering.

理工学部は、「理」に裹打ちされた専門能力と高い倫理性を持ち、学際分野にも目を向けられる、総合力で日本や 地域に貢献できる人材の育成に力を注ぎます。 $1 \cdot 2$ 年次では理学に関する教育を徹底して行い、3・4年次ではその 知識を専門という場で活用しながら身につけていきます。自ら課題を発見でき、未知の分野の課題に対しても幅広 い視野から、柔軟に解決できる能力を修得させる学士課程教育を実施します。

4 The Faculty of Engineering Science will focus on developing human resources to contribute to the development of Japan and the region by equipping them with comprehensive and professional abilities, and a highly sense of ethics, and a passion for academic fields. In the first and second year, education on science is thoroughly conducted, and in the third and fourth year, we acquire knowledge used in specialized fields. We offer a bachelor's degree education to discover problems and acquire the ability to flexibly solve open problems from a broad perspective.

理工学研究科は地域産業を担う高度な専門的職業人、地域産業を自ら生み出寸挑戦者、そして、地域に根差したグ ローバル人材を育成することを目標としています。理工学の専門性に基礎を置き新しいモノづくり・コトづくりを 目指寸人、様々な課題を抱える地域社会の発展に貢献したい人、そして、学問を通して人類の諸課題の解決に寄与 することを目指している人を入学者として求めています。社会人に対しては働きながらも学ぶ事を可能とする柔軟 な取り組みを、そして、世界各国の留学生を受け入れるグローバルな環境をそれぞれ整備し、異なる背景と目標を

5 持つ学生を積極的に受け入れます。

The goal of the Graduate School of Engineering Science is to cultivate highly skilled professionals who are responsible for regional industry, challengers who create their own regional industries, and global human resources rooted in the region. We will recruit those who aim to create new objects and things based on their expertise in science and engineering, those who want to contribute to the development of local society with various tasks, and aim to contribute to solving various problems of mankind through learning. There are flexible efforts to enable students learn while working, and environments accepting of international students from around the world, as well as students with different backgrounds and goals.

研究室では、バイオメトリクスシステムの開発、画像情報応用・保護、ヒューマンセンシング、リモートセンシン グ、故障診断などに関する研究を行っています。例えば、高度なマンマシンインタフェースを実現するために、発 話に伴う口の動きに着目し、個人認証や発話内容の識別、発話者の感情を推定する技術、並びに顔表情認識の研究 を進めています。また、ヒトの感性や視覚特性を考慮し利用者に優しいシステムを構築するために、感性情報を画 像処理技術に組み込んだ処理法の開発や、標識や看板の認識法の開発を行っています。さらに、環境モニタリング、 防災や減災に役立てるために、人工衛星などから取得されたデータの解析技術の開発を行っています。

6 The Laboratory conducts research on biometrics system development, image information application and protection, human sensing, remote sensing, fault diagnosis and so on. For example, in order to realize an advanced man-machine interface, we focus on the movement of the mouth accompanying an utterance, and we develop techniques for identifying individual authentication, the contents of utterance contents, and techniques for estimating the emotion of speakers, and for facial expression recognition. In addition, in order to build a user-friendly system in consideration of human sensitivity and visual characteristics, we develop a process that incorporates sensitivity information into image processing technology, and develop methods of recognizing signs and signs. We are also developing data analysis technology acquired from artificial satellites, etc. for the purpose of environmental monitoring, disaster prevention, and disaster reduction. 